\title{
Atomic layer deposition: Catalytic preparation and modification technique for the next generation
}

\author{
Hongbo Zhang a,*, Christopher L. Marshall b,\# \\ a School of Materials Science and Engineering \& National Institute for Advanced Materials, Nankai University, Tianjin 300350, China \\ b Chemical Sciences and Engineering Division, Argonne National Laboratory, 9700 South Cass Avenue, Lemont, IL, 60439, USA
}

\section{A R T I C L E I N F}

\section{Article history:}

Received 5 January 2019

Accepted 30 January 2019

Published 5 September 2019

\section{Keywords:}

Atomic layer deposition

Catalyst modification

Catalyst preparation

Redox properties

Terrace site

Step site

\begin{abstract}
A B S T R A C T
Atomic layer deposition (ALD) attracts great attention nowadays due to its ability for designing and modifying catalytic systems at the molecular level. There are several reported review papers published recently discussing this technique in catalysis. However, the mechanism on how the deposited materials improve the catalyst stability and tune the reaction selectivity is still unclear. Herein, catalytic systems created via ALD on stepwise preparation and/or modification under self-limiting reaction conditions are summarized. The effects of deposited materials in terms of electronic/geometry modification over the catalytic nanoparticles (NPs) are discussed. These effects explain the mechanism of the catalytic stability improvement and the selectivity modification. The unique properties of ALD for designing new catalytic systems are further investigated for building up photocatalytic reaction nanobowls, tandem catalyst and bi-active-component metallic catalytic systems. (C) 2019, Dalian Institute of Chemical Physics, Chinese Academy of Sciences. Published by Elsevier B.V. All rights reserved.
\end{abstract}

\section{Introduction}

Catalysis is important because over $90 \%$ of fuels and chemicals currently used are made through one or more catalytic steps [1]. Research in catalysis is a major field in applied science and involves many areas of chemistry, notably organic and physical chemistry with emphasis on mass/heat transfer and reaction kinetics, as well as materials science. Previously, researchers used incipient wetness impregnation, deposition-precipitation, ion-exchange or chemical vapor deposition (CVD) methods, etc. to create catalyst particles. These methods, however, are not precise resulting in catalysts with a wide range of active metal size distributions. Recently, a new method called atomic layer deposition (ALD) has been developed [2,3] and applied in catalytic studies [4-9]. ALD is a well-defined method developed for controlling metal deposition in the mi- croelectronics industry. ALD modifies the surface of either the support or the active component(s) (metal/metal oxide particles) layer by layer offering an opportunity to fine tune the local environments at the interface.

It is well established that the surface and interface structure around the active component(s) is very important for catalysis. Accordingly, a structure to reaction activity/selectivity correlation would be performed. For example, Goodman and coworkers [10] used sputtering technique to change the particle size of gold. They found that gold nano-particles with mean size around 2 to $3 \mathrm{~nm}$ show the highest $\mathrm{CO}$ oxidation activity. Shen and coworkers [11] found that crystallized $\mathrm{Co}_{3} \mathrm{O}_{4}$ nano-rods exhibit excellent activity for $\mathrm{CO}$ oxidation at temperatures as low as $-77^{\circ} \mathrm{C}$, and are sufficiently stable in feed gases with a large amount of water and carbon dioxide at $200-400{ }^{\circ} \mathrm{C}$. Thomas et al. $[12,13]$ found that four-coordinated Ti is the ac-

\footnotetext{
* Corresponding author. E-mail: hbzhang@nankai.edu.cn

\# Corresponding author. E-mail: Marshall@anl.gov

This paper is dedicated to the 100th anniversary of Nankai University, which was founded in 1919 by educators Mr. Xiu Yan and Mr. Boling Zhang. DOI: S1872-2067(19)63321-8 | http://www.sciencedirect.com/science/journal/18722067 | Chin. J. Catal., Vol. 40, No. 9, September 2019
} 
tive species in propylene epoxidation reaction. Bao and coworkers [14-17] proposed that nanoparticles confined within a limited environment show great activity, stability and sometimes higher selectivity to the desired products. They proposed that coordinated unsaturated sites (CUS sites) are the active species for catalysis in most cases. Furthermore, Schlögl et al. [18-20] found that not only the structure of the exposed component affects the catalytic reaction performance; but also subsurface components of the catalyst changes catalysis. For example, they found that the subsurface carbon and hydrogen in supported palladium systems play an important role in acetylene hydrogenation reaction. Palladium particles with carbonaceous subsurface species facilitate the ethylene formation while palladium $\beta$-hydride facilitates ethane formation [18]. All these examples suggest that the physical properties (particle size, coordination number, oxidation state, crystal structure and the subsurface component of the nanoparticle under a specific reaction condition) are very important for catalytic processes. Therefore designing/modifying catalytic systems at the atomic level attracts great attention. Fortunately, ALD [21] is such a technique to aid in the understanding of catalysis from a molecular point of view.

ALD is a well-defined synthesis technique, first found by Aleskovskii and Koltsov from the USSR Academy of Sciences [2] and further developed by Suntola and coworkers in Finland [3]. Currently, ALD is widely used in microelectronics industry for controlling metal deposition. For example, in the late 1990s, Samsung used ALD to improve the storage capacity in DRAM memories [22]. In 2007, Intel introduced ALD into their mass production line [23]. Transistor fabrication research and development rely on ALD for depositing pinhole-free, conformal films with well-controlled thickness and a high dielectric constant. ALD also shows potential for creating the next-generation fuel cells, particularly solid oxide fuel cells (SOFCs) [24] and draws great attention from people working on photovoltaics field [25].

Recently, Stair and coworkers [7] found that ALD increases the stability of a supported palladium catalyst for an oxi-dehydrogenation reaction. They speculated that the mechanism for the increased catalyst stability was due to the small pore within the ALD layer, which might be too small for carbon polymerization. Another explanation is that the active sites for coke formation are selectively covered. Shortly afterwards, the enhancement of the reaction stability has been confirmed by Dumesic and Marshall groups [26,27]. In addition, Marshall et al. [28] showed that ALD could also modify the reaction selectivity. After ALD overcoating, the generation of metal-oxide interface would also remarkably improve metal catalyst activity [29-31]. However, the mechanism of the effects of the deposited material against the nanoparticle covered is still debatable. This paper discusses how ALD overcoating changes the physical and chemical properties around the active components of catalysts and why ALD can increase catalyst stability while modifying reaction selectivity. This paper also summarizes how researchers employ this technique to design new catalytic systems at the atomic level. The wider application of this technique in electronic or photocatalysis is discussed in detail.

\section{Atomic layer deposition process}

ALD is a well-defined technique used for surface modification in microelectronics industry. The merit of this method is the facile control of the composition and thickness of the material at the atomic level. In most cases, the built up layer is amorphous as shown in Scheme 1. For this reason, the name of this process was corrected from atomic layer epitaxy (ALE), which was widely used before 2000 , to atomic layer deposition (ALD). In the mid-1970s, the ALD method was first reported by Aleskovskii and Koltsov from the USSR Academy of Sciences [2] named "molecular layering" (ML). They deposited metal oxides to the substrate by alternately exposing the substrate to metal chloride precursor and water, which is quite similar to the ALD technique applied nowadays. This method was further developed by Suntola and coworkers from Finland [3] who used this method to fabricate electroluminescent displays. ZnS films were fabricated using alternating exposures to elemental $\mathrm{Zn}$ and $\mathrm{S}$. The technique is a sequential and self-limiting method requiring binary components adsorbed to the surface. Because the number of sites on the surface of the substrate is not infinite, the adsorption of binary precursor would be terminated once all the sites were occupied. In principle, the precursor (molecular A, such as metal chloride) added to the system would first react with the functional groups (such as $-\mathrm{OH}$ group) from the surface of the substrate, and then react with the secondary molecular (molecular $\mathrm{B}$, such as $\mathrm{H}_{2} \mathrm{O}, \mathrm{NH}_{3}, \mathrm{O}_{2}, \mathrm{O}_{3}$, etc.) added to the system to complete one cycle of ALD. Then a monolayer of surface species would be assembled. This is a very precise technique. As illustrated in Figure 1, the mass gain and the thickness of tungsten deposited was step-wise linearly correlated to the number of ALD cycles by feeding $\mathrm{WF}_{6}$ and $\mathrm{Si}_{2} \mathrm{H}_{6}$ separately as the reactants [32].

The substrate of the ALD treatment is not limited to single crystals. Dispersed nanoparticles (NPs) are widely used as active components for creating catalysts. The surface of the parti-

\section{Atomic Layer Deposition (ALD)}

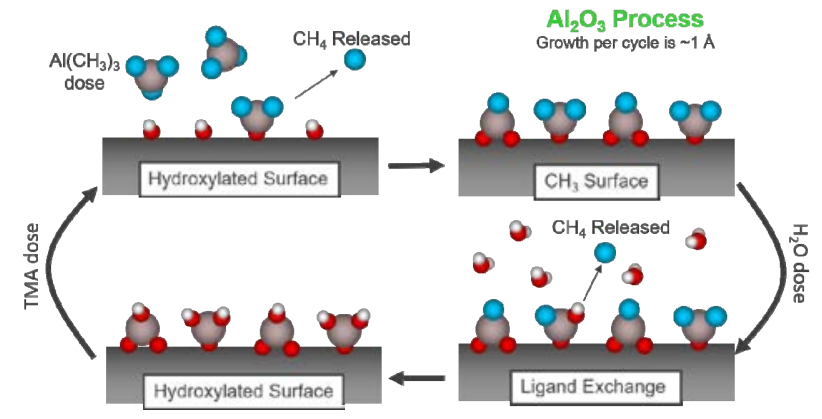

Scheme 1. Schematic representation for making a mono layer of alumina film via ALD overcoating using $\mathrm{Al}\left(\mathrm{CH}_{3}\right)_{3}$. The overcoated surface is pre-covered with hydroxy groups. $\mathrm{Al}\left(\mathrm{CH}_{3}\right)_{3}$ is then dosed to the system to react with the hydroxy groups. One mono layer of aluminate is fixed to the surface of the substrate. Extra organic ligands are released as $\mathrm{CH}_{4}$ by re-dosing with water that generates new hydroxyl groups for subsequent Al layers. 


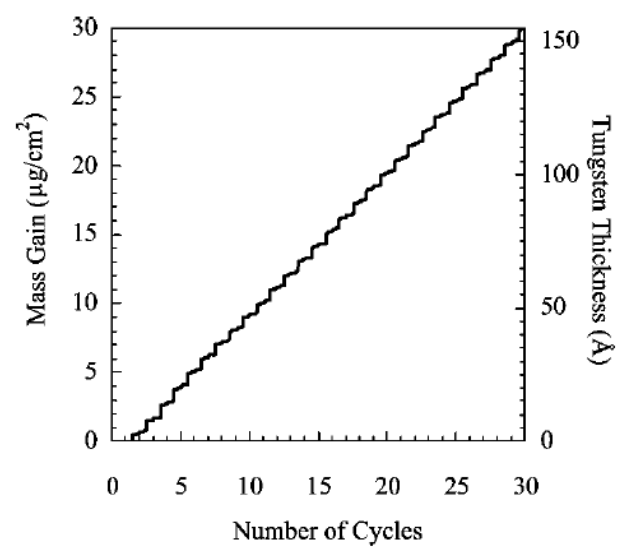

Fig. 1. Mass gain monitored by quartz crystal microbalance for $30 \mathrm{cy}-$ cles during $\mathrm{W}$ ALD using $\mathrm{WF}_{6}$ and $\mathrm{Si}_{2} \mathrm{H}_{6}$ as the reactants. The corresponding tungsten thickness has been calculated assuming a density of $19.3 \mathrm{~g} / \mathrm{cm}^{3}$. Reprinted with permission from Ref. [32]. Copyright 2005 Elsevier.

cle can be modified by ALD once its surface was grafted with desired functional groups, such as $-\mathrm{OH}$. The thickness of the ALD layer is proportional to the ALD cycles as described in Figure 1 [32]. Figure 2 shows transmission electronic microscopy (TEM) analysis of different cycles of alumina ALD modified palladium nanoparticles (NPs). (Figure 2a-c) [4] Clearly, the thicknesses of alumina ALD layers applied are linearly correlated to the cycles of alumina ALD, even though the substrate is Pd NPs (Figure 2d). $\mathrm{ALD} \mathrm{Al}_{2} \mathrm{O}_{3}$ layers could be precisely deposited on Pd nanoparticle catalysts at a growth rate of $\sim 1.6$ $\AA$ /cycle (Figure $2 \mathrm{~d}$ ). Since the reaction temperature for alumina ALD is not high $\left(\sim 200^{\circ} \mathrm{C}\right)$, the size distributions of Pd NPs with and without ALD overcoating are quite similar (Figure 2e) [28], demonstrating that after ALD treatment, the structure of active component (the particle size of Pd NPs) can be preserved. Actually, with a thin layer on top of the metal oxide NPs, agglomeration of the particles is minimized. The thickness of the ALD

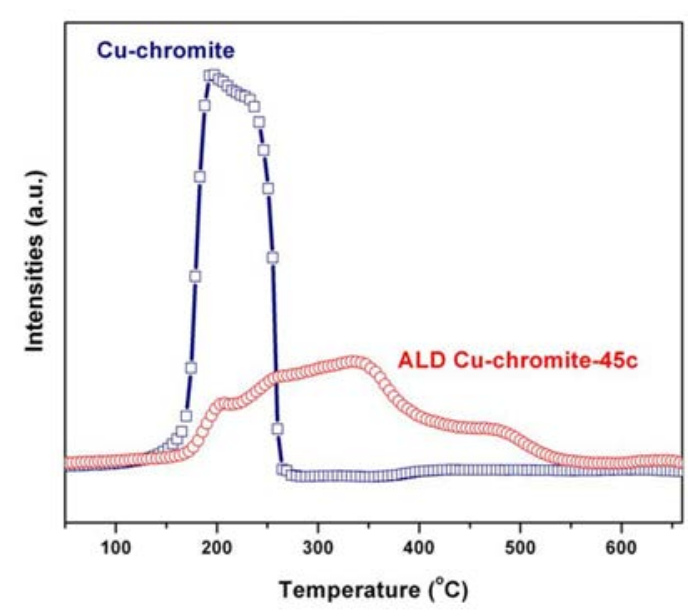

Fig. 3. Reverse hydrogen consumption intensities from TCD during temperature programmed reduction at the heating rate of $5{ }^{\circ} \mathrm{C} / \mathrm{min}$ of Cu-chromite ( $\square$ ) and ALD Cu-chromite-45c ( $\circ$ ) by feeding $4 \%$ hydrogen in Argon. Reprinted with permission from Ref. [27]. Copyright 2014 Elsevier.

coating is controlled to within nano-meters, minimizing diffusion limitations within the ALD layers, which is a great advantage in kinetic studies compared to other confined reaction systems with metal nanoparticles trapped in channels.

\section{Modification effect of ALD}

\subsection{Tuning of catalytic redox properties}

The interactions between the ALD layer and the nanoparticles underneath are influenced by the texture of layer applied. For example, a reducible metal oxide, such as $\mathrm{TiO}_{2}, \mathrm{CeO}_{2}$, etc., shows some electronic interactions, while non-reducible metal oxide layers, such as $\mathrm{SiO}_{2}$ and $\mathrm{Al}_{2} \mathrm{O}_{3}$, are inert. However, there might be exceptions. For example, as shown in Figure 3, the
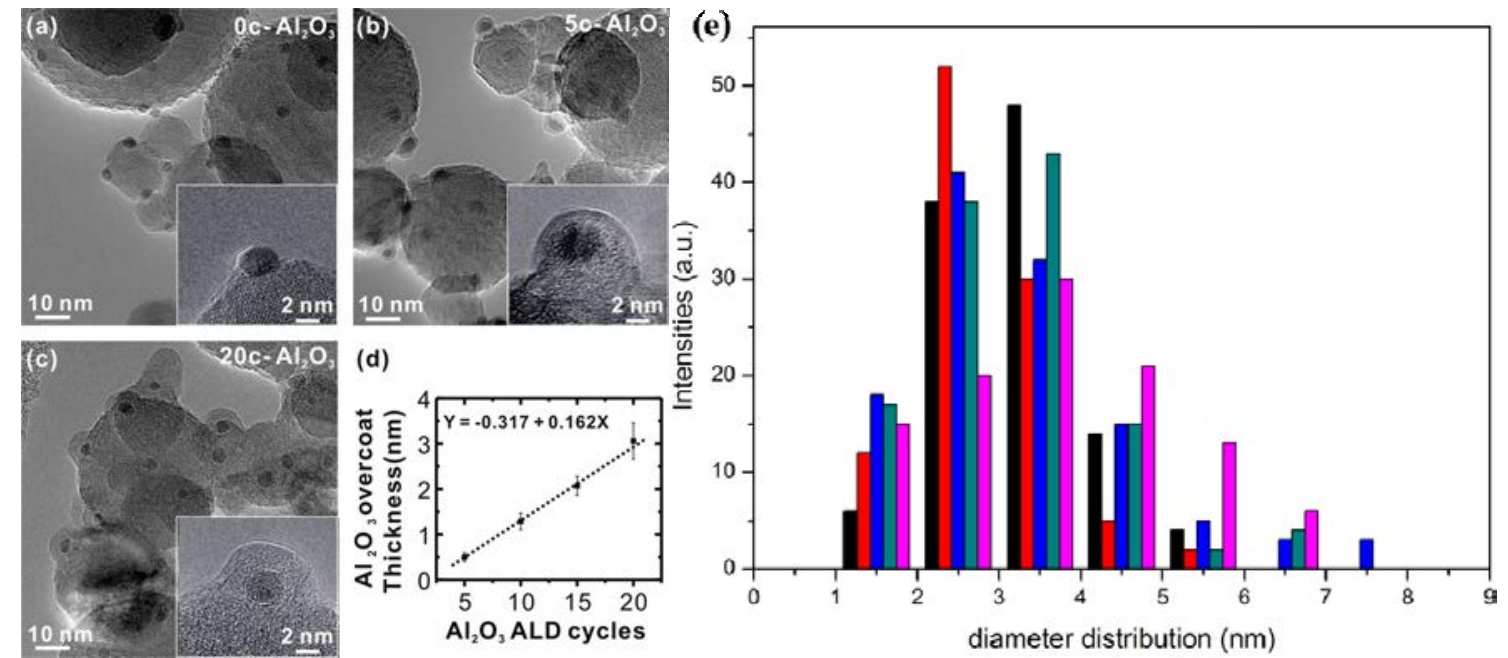

Fig. 2. TEM images of $\mathrm{Pd} / \mathrm{Al}_{2} \mathrm{O}_{3}$ catalysts on spherical alumina support following different numbers of $\mathrm{ALD}_{2} \mathrm{Al}_{2} \mathrm{O}_{3}$ overcoating cycles (insets show higher magnification images). (a) Without overcoating; (b) 5 cycles $\mathrm{Al}_{2} \mathrm{O}_{3}$; (c) 20 cycles $\mathrm{Al}_{2} \mathrm{O}_{3}$; (d) thickness of $\mathrm{Al}_{2} \mathrm{O}_{3}$ overcoats versus $\mathrm{ALD}$ cycles. Reprinted with permission from ref [1]. Copyright 2012 American Chemical Society. (e) size distribution of $\mathrm{Pd}-2 \mathrm{wt} \% / \mathrm{Al}_{2} \mathrm{O}_{3}\left(-\right.$, black), $\mathrm{Pd}-5 \mathrm{wt} \% / \mathrm{Al}_{2} \mathrm{O}_{3}$ (一, purple), ALD Pd/ $\mathrm{Al}_{2} \mathrm{O}_{3}-10 \mathrm{c}\left(-\right.$, red), $\mathrm{ALD} \mathrm{Pd} / \mathrm{Al}_{2} \mathrm{O}_{3}-20 \mathrm{c}\left(-\right.$, blue) and ALD Pd/ $\mathrm{Al}_{2} \mathrm{O}_{3}-30 \mathrm{c}(-$, cyan). Reprinted with permission from ref [28]. Copyright 2014 Wiley-VCH. 
reduction temperature of an alumina ALD modified $\mathrm{Cu}$ (reversed hydrogen consumption signal) was increased by about $300{ }^{\circ} \mathrm{C}$ comparative to an uncoated copper catalyst with a reduction temperature at $\sim 250{ }^{\circ} \mathrm{C}$ [25]. The lowered reduction temperature was shown to be due to the formation of a copper aluminate phase at the interface between the ALD layer and copper nanoparticle. This illustrates that the modification effect from the ALD layer to the nanoparticle covered is complex. It cannot be simply grouped based on the textures of the ALD layers (reducible or non-reducible) on top of the metal nanoparticles. Figure 5 shows the reversed signals on consumption of hydrogen as a function of temperature, where the oxidation state of copper during hydrogenation is still unclear.

In order to determine the actual chemical state of copper during hydrogen reduction, in-situ XAFS measurements were applied to both an uncoated copper catalyst (Cu-chromite) and copper catalyst overcoated by alumina ALD (ALD Cu-chromite 45c-700). In Figure 4, normalized stacked plots of the $\mathrm{Cu}$ K-edge XANES of Cu-chromite and ALD Cu-chromite-45c-700 were collected during the in-situ XAFS/ $/ \mathrm{H}_{2}$-TPR experiment. Comparing the XANES features of alumina ALD $\mathrm{Cu}$-chromite-45c-700 with uncoated $\mathrm{Cu}$-chromite $\mathrm{C} \mathrm{Cu}$ foil, $\mathrm{Cu}_{2} \mathrm{O}$ and $\mathrm{CuO}$ as standards), there are two peaks above the absorp- tion edge and higher intensity for the second peak are clearly different from that of $\mathrm{Cu}$-chromite with only a single peak above the absorption edge corresponding to neither $\mathrm{Cu}$ nor CuOx. Actually, the feature of the overcoated sample is quite similar to copper aluminate in the literature. In addition, copper aluminate could be generated by heating $\mathrm{Cu} / \mathrm{Al}_{2} \mathrm{O}_{3}$ to $>700$ ${ }^{\circ} \mathrm{C}$, quite similar to our ALD pretreatment procedure [33]. The reduction temperature for alumina ALD coated sample is about $300{ }^{\circ} \mathrm{C}$ higher than uncoated copper catalyst in both $e x$-situ and in-situ hydrogenation reactions. Notably, the ALD overcoated catalyst (ALD Cu-chromite-45c-700) was not completely reduced until about $650{ }^{\circ} \mathrm{C}$ while $\mathrm{Cu}$-chromite reduces from $\mathrm{Cu}^{2+}$ to $\mathrm{Cu}^{0}$ in a relatively narrow temperature range between 200 and $300{ }^{\circ} \mathrm{C}$ (Figure 4b). An XANES linear combination fitting was applied to the in-situ XAFS/ $\mathrm{H}_{2}$-TPR measurements, an example on how this linear fitting was done is shown in Figure 4c. The LC fitting results of the in-situ measurement over bare and ALD copper catalysts are shown in Figure 4d. It reveals the evolution of $\mathrm{Cu}^{2+}$ and $\mathrm{Cu}^{0}$ as a function of temperature in both cases with the absent of $\mathrm{Cu}^{1+}$ species suggesting that the reduction of $\mathrm{Cu}^{1+}$ to $\mathrm{Cu}^{0}$ is much faster than the reduction from $\mathrm{Cu}^{2+}$ to $\mathrm{Cu}^{1+}[34,35]$. This quantitative analysis reinforces that the $\mathrm{Cu}$ reduction was modified by the $\mathrm{ALD}_{2} \mathrm{Ol}_{3}$ overcoating.
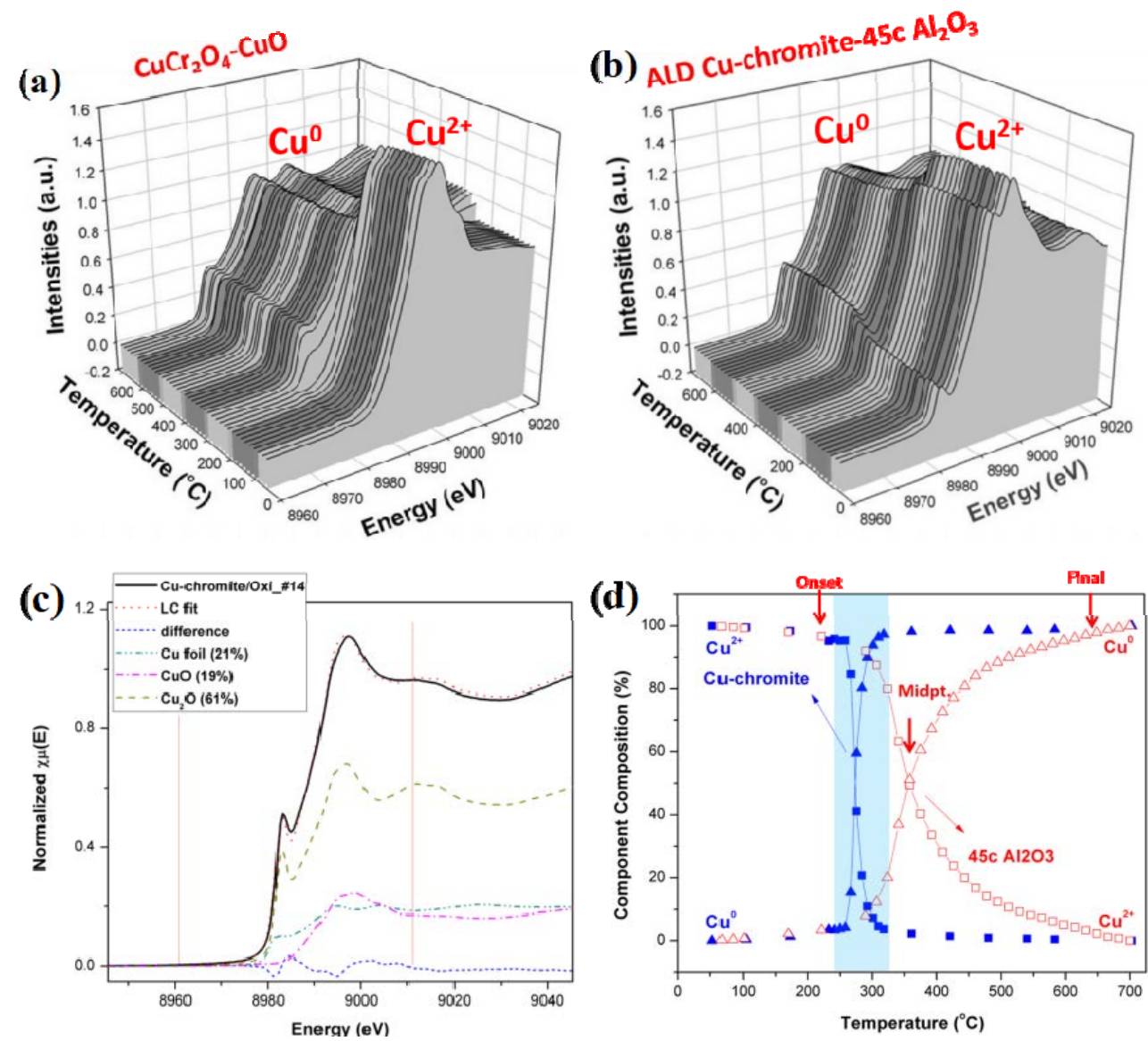

Fig. 4. Stacked normalized $\mathrm{Cu}$ K-edge XANES spectra of (a) Cu-chromite and (b) ALD Cu-chromite-45c-700 collected during the in-situ $\mathrm{H}_{2}$-TPR experiment in $4 \% \mathrm{H}_{2} / \mathrm{Ar}$ at $5{ }^{\circ} \mathrm{C} / \mathrm{min}$; (c) Linear combination (LC) fit of one spectrum of $\mathrm{Cu}$ K-edge XANES from the literature (reprinted with permission from Ref. [31], copyright 2005 Elsevier) and (d) percent of $\mathrm{Cu}^{2+}(\mathbf{\square}, \square)$ and $\mathrm{Cu}^{0}(\boldsymbol{\Delta}, \Delta)$ species as a function of temperature during in-situ $\mathrm{H}_{2}$-TPR from XANES data by factor analysis over Cu-chromite and ALD Cu-chromite 45c-700 (Reprinted with permission from Ref. [27], copyright 2014 Elsevier). 

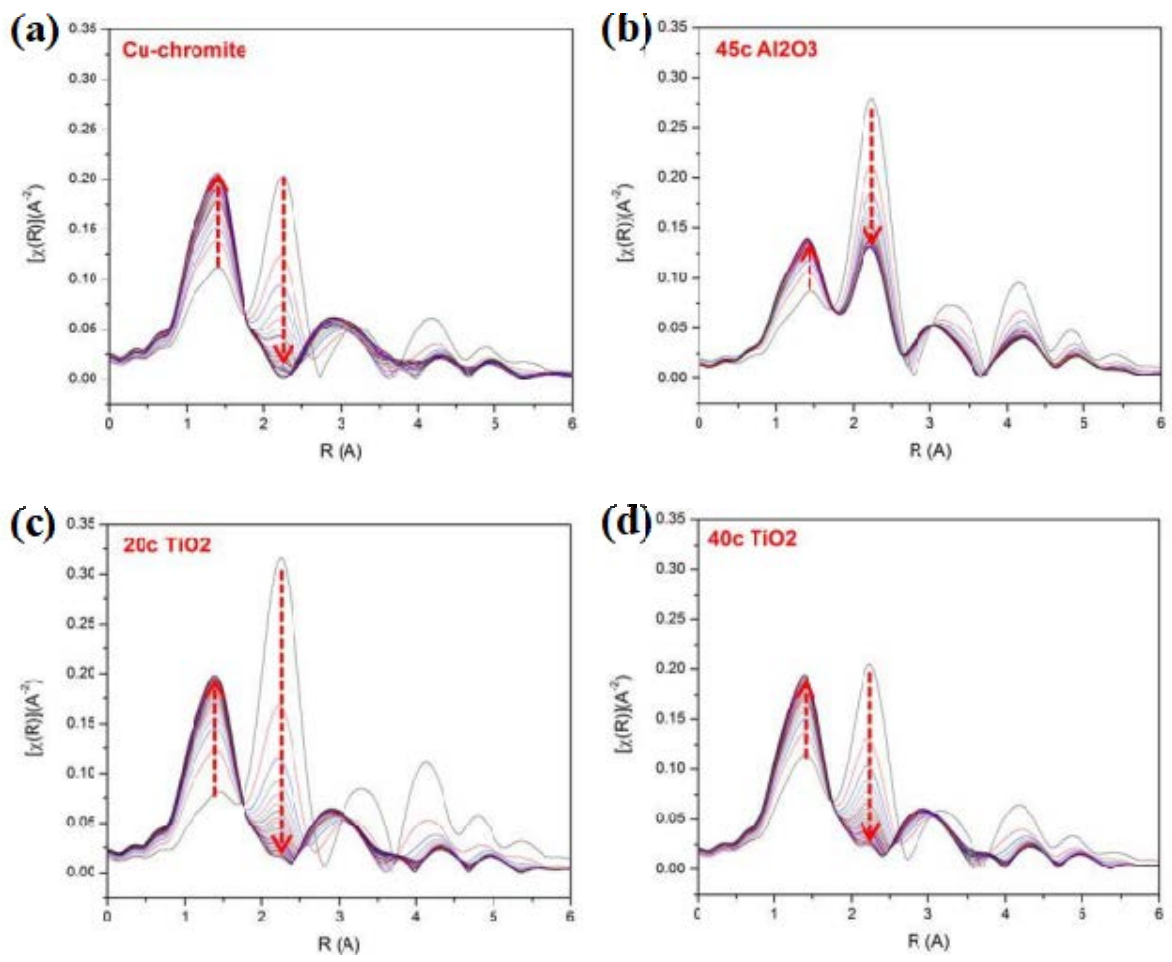

Fig. 5. Fourier transform magnitude of the $\mathrm{Cu}$ K-edge EXAFS spectra of (a) Cu-chromite, (b) $45 \mathrm{c}_{2} \mathrm{Al}_{3}$, (c) $20 \mathrm{c} \mathrm{TiO}_{2}$, and (d) $40 \mathrm{c} \mathrm{TiO}_{2}$ calcined in air at $150{ }^{\circ} \mathrm{C}$ for $8 \mathrm{~h}$ after reduction at $400^{\circ} \mathrm{C}$ for $60 \mathrm{~min}$. The interval between two nearest spectra is $17 \mathrm{~min}\left(k\right.$-range from $2.0 \AA^{-1}$ to $12.8 \AA^{-1}, k \chi(\mathrm{k})$ EXAFS function). Note that the initial spectra are not at $t=0 \mathrm{~min}$ and some reoxidation has occurred before the first measurement. Reprinted with permission from Ref. [36]. Copyright 2015 Elsevier.

Not only the reduction profile of the copper modified by the alumina ALD overcoating, but also the oxidation of copper suggests that the redox properties of the nanoparticle covered can be tuned by ALD. The fourier transform magnitudes of the $\mathrm{Cu}$ K-edge EXAFS spectra of $\mathrm{Cu}$-chromite, $45 \mathrm{c}_{2} \mathrm{O}_{3}, 20 \mathrm{c} \mathrm{TiO}$, and $40 \mathrm{c} \mathrm{TiO}_{2}$ are included in Figure 5, in which the samples were calcined in situ in air at $150{ }^{\circ} \mathrm{C}$ for $8 \mathrm{~h}$ after reduction at $400{ }^{\circ} \mathrm{C}$ for $60 \mathrm{~min}$. At the beginning, the predominant peak in the Fourier transform (FT) is the $\mathrm{Cu}-\mathrm{Cu}$ path, which is the nearest neighbor for $\mathrm{Cu}^{0}$ nanoparticles, being indicated by the downward-pointing arrow. As oxidation proceeds, copper is slowly oxidized and magnitude of the $\mathrm{Cu}-0$ path (from $\mathrm{Cu}^{1+}$ or $\mathrm{Cu}^{2+}$ ) increases, indicated by the upward-pointing arrow. Over $8 \mathrm{~h}$, large oxidation state changes are observed for all four catalysts. The $45 \mathrm{c} \mathrm{Al}_{2} \mathrm{O}_{3}$-coated material shows the least oxidation, suggesting that the redox properties of $\mathrm{Cu}$-chromite were changed by alumina ALD similar to the previously reported results for a $\mathrm{H}_{2}$-TPR experiment on alumina-ALD-overcoated catalysts [27]. As stated above, this oxidation resistance is most likely due to the formation of copper aluminate after alumina ALD overcoating.

The oxidation profiles of the $20 \mathrm{c} \mathrm{TiO}_{2}$ and $40 \mathrm{c} \mathrm{TiO}_{2}$ are quite similar to $\mathrm{Cu}$-chromite before ALD overcoating, suggesting that $\mathrm{TiO}_{2}$ has a smaller chemical influence on the redox properties of copper than alumina ALD. This implies that there is no copper titanate formed during $\mathrm{TiO}_{2}$ ALD overcoating or the subsequent sample treatment. Overall, the modification effect of ALD can be influenced by precursors applied.

\subsection{Preferentially coverage of step sites}

In catalysis, not only do the redox properties of the active component affect the reaction performance but also the structure of the active composition, the so-called geometric effect discussed in the introduction of this paper. If the local environment around the active component of the catalyst is changed by the ALD overcoating, the reaction performance can also be modified. Recently, Feng et al. [37] found from the CO chemisorption with DRIFTS analysis that the $\mathrm{ALD} \mathrm{Al}_{2} \mathrm{O}_{3}$ initiated preferential overcoated the Pd edge and corner sites as seen by the loss of bridged and linear CO peaks at 1978 and $2095 \mathrm{~cm}^{-1}$, respectively (Figure 6). Because the Pd atoms at the low-coordination sites contribute little to the dehydrogenation reaction along methanol decomposition based on the research from the literature [38], the catalytic activity was not affected by the first few steps of $\mathrm{ALD} \mathrm{Al}_{2} \mathrm{O}_{3}$ overcoats. As the number of $\mathrm{ALD} \mathrm{Al}_{2} \mathrm{O}_{3}$ overcoating cycles increases, the $\mathrm{Al}_{2} \mathrm{O}_{3}$ deposit begins to intrude on the Pd(111) sites eventually leading to complete particle encapsulation. No CO chemisorption was detected on the $24 \mathrm{c}-\mathrm{Al}_{2} \mathrm{O}_{3}$ overcoated Pd sample (Figure 6). Stair and coworkers [7] also proposed that overcoating Pd NPs via alumina ALD would preferentially cover the step sites thought to be the active sites for coke formation. Because of this, the reaction stability was improved. Since coke formation can be considered as one of the products, ALD was shown to improve selectivity in their ethane oxi-dehydrogenation reaction. 


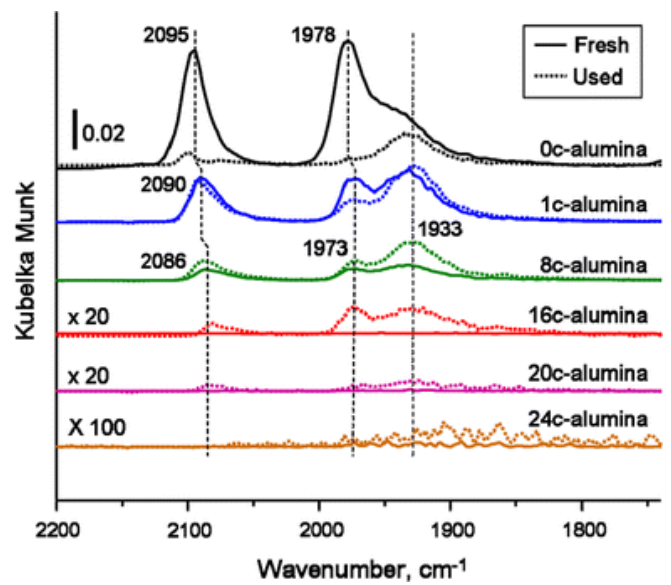

Fig. 6. DRIFTS spectra of CO chemisorbed to saturation coverage on fresh (solid lines) and used (doted lines) Pd catalysts with different numbers of $\mathrm{ALD} \mathrm{Al}_{2} \mathrm{O}_{3}$ over-coating cycles $(0 \mathrm{c}$ (-, black), 1c- (-, blue), 8c- (-, cyan), 16c (-, red), 20c- (-, purple) and 24c- $\mathrm{Al}_{2} \mathrm{O}_{3}$ (-, yellow)). Spectra for fresh and used $16 \mathrm{c}\left(-\right.$, red), 20c- $\mathrm{Al}_{2} \mathrm{O}_{3}(-$, purple) samples were enlarged by $\times 20$. Spectra for fresh and used $24 \mathrm{c}-\mathrm{Al}_{2} \mathrm{O}_{3}$ (- yellow) samples were enlarged by $\times 100$. (Reprinted with permission from ref [37]. Copyright 2011 Springer.)

\subsection{Precise generation of pore structure}

As discussed above, ALD is an excellent technique for the modification of catalytic surfaces. It is precise, easy to handle and shows great potential in future industrial catalytic applications. However, two obstacles still exist for its future commercial use. The first is cost since both the ALD precursor and reactors are significantly more expensive than current commercial techniques. The second is that the mechanism controlling the pore structure within the ALD layer is still unclear. For catalytic applications, the reactant(s) must contact the surface of the catalyst. That is why it is necessary to do a high temperature calcination to generate pores within the ALD layers before catalytic applications. However, since the crystal-structure of the ALD layer is amorphous this pore structure is hard to analyze quantitatively. Small angle X-ray scattering (SAXS) is a characterization method that can quantitatively analyze the pore structure of the amorphous species, such as polymers [39]. It is also suitable for studying the pore size distribution within ALD layers. Winans et al. [40] did a fair amount of work with this technique on ALD overcoated materials. In Figure 7, air scattering and parasitic scattering were determined by performing a measurement using an empty quartz capillary [40]. The SAXS range was calibrated with a silver behenate standard. Quantitative data analysis of the SAXS patterns were performed using cylindrical form factors with a maximum entropy algorithm via the Irena package [39]. Representative SAXS data for 15 cycles of $\mathrm{ALD} \mathrm{Al}_{2} \mathrm{O}_{3}$ on $\mathrm{CAL}-\mathrm{TiO}_{2}$ (P-tert-butyl-calix[4]arene modified $\mathrm{TiO}_{2}$ ) are included in Figure 7a. The low-q region exhibits a $\mathrm{q}^{4}$ dependency associated with Porod scattering from the support particles with broad size distributions. Subtraction of this component leaves the scattering associated only with the nanocavities. The pore scattering curve obtained for 15 cycles $\mathrm{Al}_{2} \mathrm{O}_{3}$ on $\mathrm{CAL}-\mathrm{TiO}_{2}$ compares well with the fitted data (blue line) in Figure $7 \mathrm{~b}$. The associated cavity size distribution is also plotted (red). Raw SAXS data for $0,5,10$, and 15 cycles ALD $\mathrm{Al}_{2} \mathrm{O}_{3}$ on $\mathrm{CAL}-\mathrm{TiO}_{2}$ is shown in Figure $7 \mathrm{c}$. Cavity size distributions for 5,10 , and 15 cycles $\mathrm{ALD} \mathrm{Al}_{2} \mathrm{O}_{3}$ on $\mathrm{CAL}_{-} \mathrm{TiO}_{2}$ are given in Figure $7 \mathrm{~d}$. After 5 cycles, the scattering was consistent with cylinders $5 \AA$ deep and averaging $10.5 \AA$ in diameter. After 10 cycles, the diameter had not changed appreciably, but the cylinder depth increased to $11 \AA$, consistent with the thicker ALD layer. After 15 cycles, the apparent depth had further increased to $15 \AA$, and the diameter increased to accommodate the tert-butyl groups on the upper rim of the cone-shaped CAL. Clearly, using SAXS analysis, people can quantitatively characterize the pore size distribution within ALD layers.

\section{Catalytic modification by ALD}

\subsection{Enhancing catalytic stability}

A thin layer of alumina ALD would be expected to shut down the reaction activity of the nanoparticles covered by preventing reactants from adsorbing to the surface of the nanoparticle. However, Stair and coworkers [7] recently found that the ALD modified Pd NPs showed great advantages in oxi-dehydrogenation of ethane following calcination of the ALD modified catalyst, in which case some nanopores would be generated. This oxi-dehydrogenation reaction was carried out at $\sim 675^{\circ} \mathrm{C}$. The uncoated Pd catalyst is usually not stable under such reaction conditions (ethane, oxygen at $\sim 675^{\circ} \mathrm{C}$ ) due to severe coke formation (Figure 8 , diamond shape signals). CO and $\mathrm{CO}_{2}$ were detected as the main products, at a yield of $12 \%$ and $6 \%$, respectively, whereas the yield of the desired product, ethylene, was only $1.9 \%$. The bare Pd NPs are not stable under these reaction conditions. All product yields quickly decreased to zero in less than $30 \mathrm{~min}$ when the reactor was completely plugged by coke and the reaction stopped. In comparison, 45 cycles of $\mathrm{ALD} \mathrm{Al}_{2} \mathrm{O}_{3}$ overcoated Pd NPs show exceptional activity for ethylene formation and long term reaction stability (Figure 8, round shape signals). Under the steady state, ethane and oxygen conversions were determined at 37\% and 99\%, respectively. Surprisingly, the yield of ethylene increased from $\sim 12.5 \%$ to $\sim 22.5 \%$ within the initial $500 \mathrm{~min}$ of the reaction tested (Figure 8) and stabilized at $\sim 22.5 \%$ for another 1200 min. This ethylene formation yield is competitive with the best catalysts for ODHE reported [41-44]. The yields of undesired products $\left(\mathrm{CO}, \mathrm{CO}_{2}\right.$, and $\left.\mathrm{CH}_{4}\right)$ were both suppressed and stable at $5.1 \%, 3.9 \%$, and $0.9 \%$, respectively. This work clearly shows that both the reaction selectivity and stability of the catalyst can be improved by ALD overcoating, even though the mechanism is not clear. The author proposed that the active sites for coke formation were selectively covered thus improving the stability of ODHE catalyst. The authors did not provide clear explanations regarding why or how the selectivity has been changed.

In another paper, Marshall et al. [27] confirmed that the ALD overcoating could increase the stability of catalysis. They found that the stability of a gas-phase furfural hydrogenation catalyst $\left(\mathrm{CuCr}_{2} \mathrm{O}_{4} \cdot \mathrm{CuO}\right)$ was enhanced by depositing a thin $\mathrm{Al}_{2} \mathrm{O}_{3}$ layer using ALD. From their research, the agglomeration of the cop- 


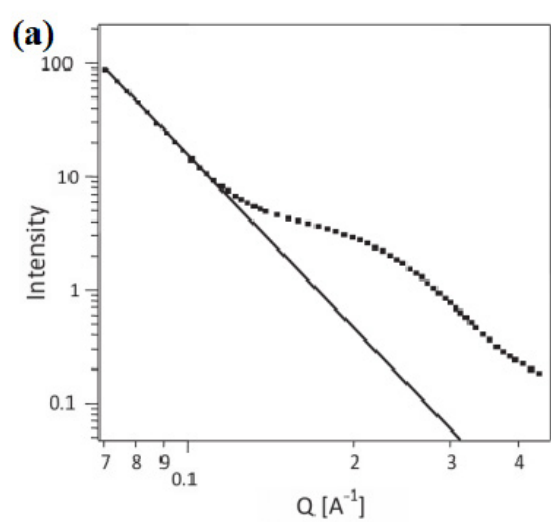

(c)

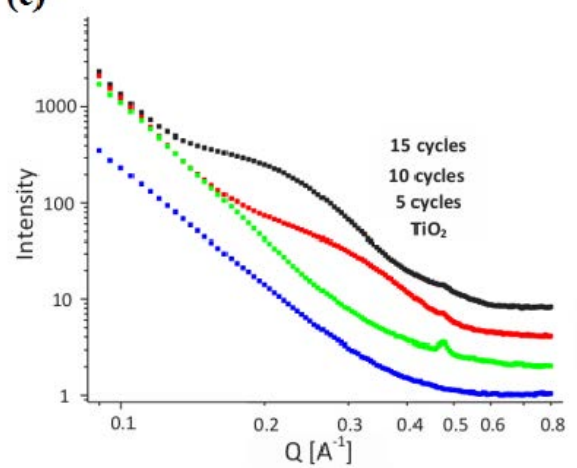

Cavity diameter $[\mathrm{A}]$

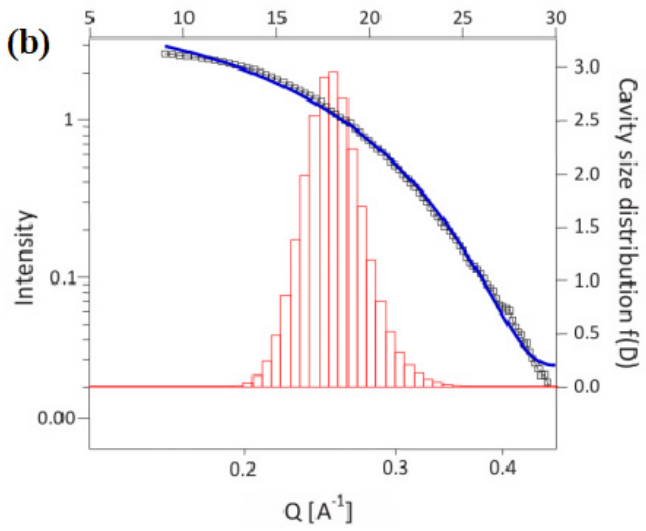

(d)

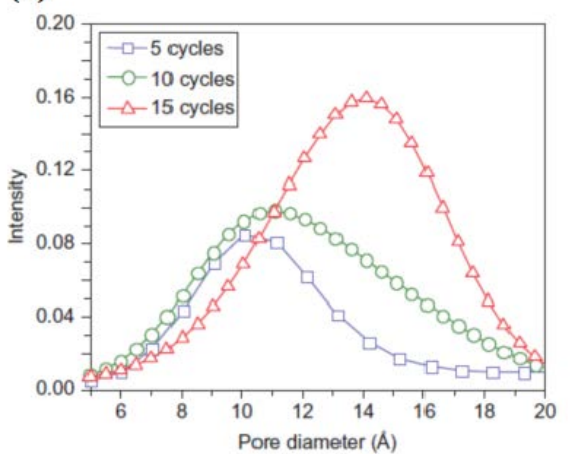

Fig. 7. (a) Representative SAXS data (•, black) for 15 cycles of $\mathrm{ALD}^{-} \mathrm{Al}_{2} \mathrm{O}_{3}$ on $\mathrm{CAL}-\mathrm{TiO}_{2}$, as synthesized. Solid line was included to guide the eye. (b) The pore scattering curve ( $\square$ ) obtained for 15 cycles $\mathrm{Al}_{2} \mathrm{O}_{3}$ on $\mathrm{CAL}^{-\mathrm{TiO}_{2}}$ compares well with the fitted data (一, blue). The associated cavity size distribution is also plotted (口). (c) Raw SAXS data for $0\left(\bullet\right.$, blue), 5 (•, green), $10\left(\bullet\right.$, red), and $15\left(\bullet\right.$, black) cycles $\mathrm{ALD} \mathrm{Al}_{2} \mathrm{O}_{3}$ on CAL-TiO 2 are shown. (d) SAXS data for 5 ( $\square$ ) $10(\circ)$ and $15(\triangle)$ cycles of $\mathrm{Al}_{2} \mathrm{O}_{3} \mathrm{ALD}$ on CAL-TiO ${ }_{2}$ are fitted as distributions of cylindrical nanocavities with heights the same as the film thicknesses. Average diameters are $10 \AA$ at 10 cycles and less, rising to $15 \AA$ for 15 cycles. (Reprinted with permission from ref [39]. Copyright 2012 Nature.)

per nanoparticles, the migration of the chromite support and the coke formation on top of the catalysts were all suppressed by ALD. Similar research by O' Neal et al. from the University of

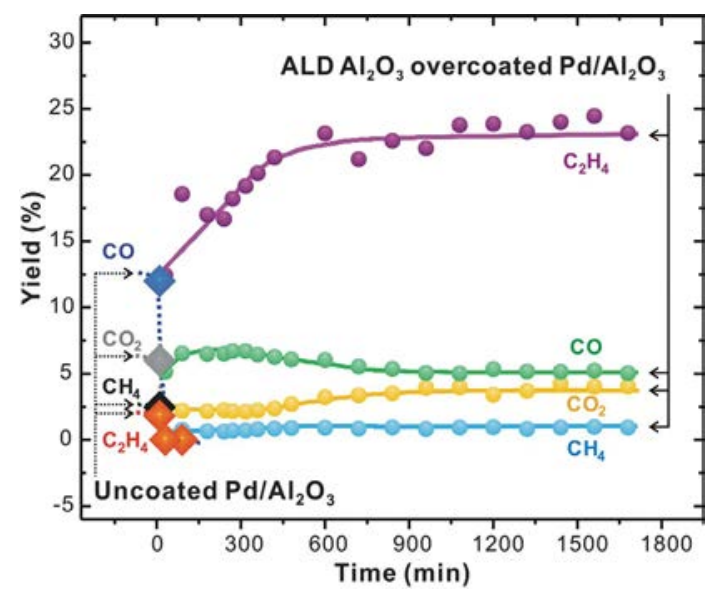

Fig. 8. Products yield on the $\mathrm{Pd} / \mathrm{Al}_{2} \mathrm{O}_{3}$ samples with (round shape) and without (diamond shape) $\mathrm{ALD} \mathrm{Al}_{2} \mathrm{O}_{3}$ overcoat during ODHE reaction as a function of reaction time under identical reaction conditions. Diamonds with a dashed line, product yields on the uncoated $\mathrm{Pd} / \mathrm{Al}_{2} \mathrm{O}_{3}$ sample; circles with solid lines, product yields on the $45 \mathrm{Al} / \mathrm{Pd} / \mathrm{Al}_{2} \mathrm{O}_{3}$ sample. Reprinted with permission from Ref. [7]. Copyright 2012 American Chemical Society.
Wisconsin [26] found that the leaching of copper in the solution was also eliminated in furfural hydrogenation reaction in the solvent. Marshall's work also shows that the $20 \mathrm{c} \mathrm{TiO}_{2}$ catalyst exhibits only about a $15 \%$ loss in activity (from its maximum) after 10-h on stream [36]. In addition, the activity remaining after the 12 -h run (about $75 \%$ of the initial $\mathrm{Cu}$-chromite activity) is much higher than the activity of Cu-chromite after only 10 -h on stream ( $<20 \%$ of initial activity). Therefore, a thin $\mathrm{TiO}_{2}$ ALD overlayer dramatically increases the stability of the $\mathrm{Cu}$ nanoparticles while maintaining the reaction activity at $\sim 75 \%$ of its maximum reaction rate. All these studies demonstrate that the ALD overcoating is a good method for improving the stability of the catalysts. Beyond that, the ALD overcoating can change the physical properties of the catalysts at the interface, which was proved to be very most important in heterogeneous catalysis.

\subsection{Tuning catalytic selectivity}

Since the structure of the exposed nanoparticles is modified by ALD overcoating, the process might be useful for changing the selectivity of a structurally sensitive reaction such as the hydrogenation of furfural. Pang et al. [45] found that in furfural hydrogenation reaction, furan was favored on the terrace site 


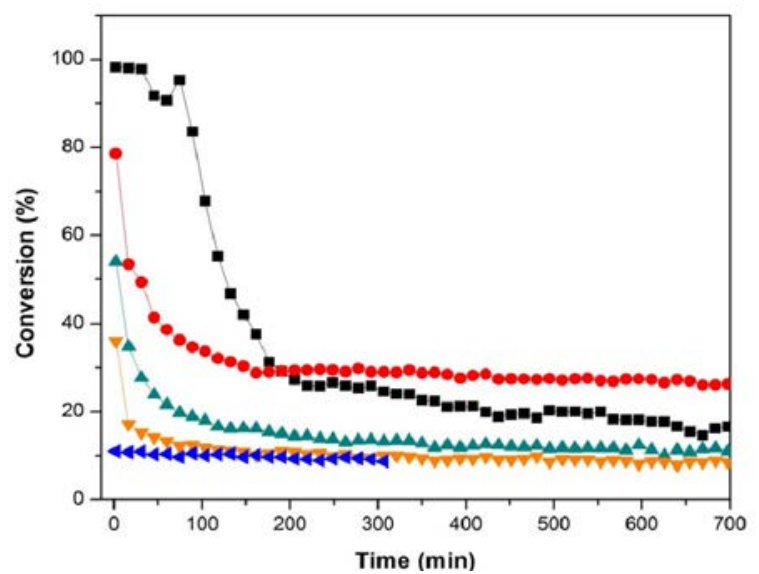

Fig. 9. Reaction conversion of furfural hydrogenation as a function of time over Cu-chromite (घ), ALD Cu-chromite-10c-700 (•), ALD Cu-chromite-20c-700 ( $\mathbf{\Delta})$, ALD Cu-chromite-30c-700 ( $\boldsymbol{\nabla})$ and ALD Cu-chromite-45c-700 (४). Reprinted with permission from Ref. [27]. Copyright 2014 Elsevier.

of Pd NPs, while furfural alcohol was favored on the step sites. Site selective modification of the Pd catalyst was achieved by self-condensation of different alkanethiolates on the surface of palladium while the reaction was carried out in the solvent. They found that $\mathrm{C}_{18}$ alkanethiolate preferentially occupied terrace sites while adamantane alkanethiolate preferentially occupied the step sites. However, the alumina overcoating by ALD should be more stable and easier to both synthesize and apply than the coating obtained by the alkanethiolate self-assembly method.

In our work, alumina ALD was tested in furfural hydrogenation reaction where the ALD process was carefully controlled [28]. We found that plotting the selectivity for furan versus the furfural conversion with the palladium catalysts $(2 \mathrm{wt} \%$ $\mathrm{Pd} / \mathrm{Al}_{2} \mathrm{O}_{3}, 5$ wt $\% \mathrm{Pd} / \mathrm{Al}_{2} \mathrm{O}_{3}, \quad 10 \mathrm{c}-\mathrm{Al}_{2} \mathrm{O}_{3} 2$ wt $\% \mathrm{Pd} / \mathrm{Al}_{2} \mathrm{O}_{3}$, $20 \mathrm{c}-\mathrm{Al}_{2} \mathrm{O}_{3} 2$ wt $\% \mathrm{Pd} / \mathrm{Al}_{2} \mathrm{O}_{3}$ and $30 \mathrm{c}-\mathrm{Al}_{2} \mathrm{O}_{3} 2$ wt $\% \mathrm{Pd} / \mathrm{Al}_{2} \mathrm{O}_{3}$ ) reveals a linear correlation (Figure 10). The linearity covers the range from $2 \%$ to $24 \%$ furfural conversion at $190{ }^{\circ} \mathrm{C}$. The slope of the linear correlation is different between bare and ALD modified palladium catalysts. $5 \mathrm{wt} \% \mathrm{Pd} / \mathrm{Al}_{2} \mathrm{O}_{3}$ catalyst shows a greater dependency between the furan selectivity and furfural conversions. This change is due to the intrinsic properties of the catalyst, e.g., the turnover frequency, and related to the relative activity of each site and not to the number of active sites. As shown in Figure 10, this correlation is not temperature-dependent (i.e., the slopes are the same when the reaction temperature is increased to $210^{\circ} \mathrm{C}$ ). The slopes for the coated catalysts are even greater than those obtained with $\mathrm{Pd}-5$ $w t \% / \mathrm{Al}_{2} \mathrm{O}_{3}$, followed by $\mathrm{Pd}-2 \mathrm{wt} \% / \mathrm{Al}_{2} \mathrm{O}_{3}$. Higher loadings of $\mathrm{Pd}$ should result in larger NPs and a greater percentage of terrace sites versus step sites. In addition, the alumina ALD overcoated catalysts should have an even higher percentage of terrace sites because the overcoatings are nucleated from the step sites of the Pd NPs as proposed by Feng et al. [37]. They proposed that the defect sites in Pd NPs can be fully covered by eight ALD cycles of $\mathrm{Al}_{2} \mathrm{O}_{3}$. Therefore, most of the remaining active sites after ten ALD cycles of alumina overcoating should be terrace

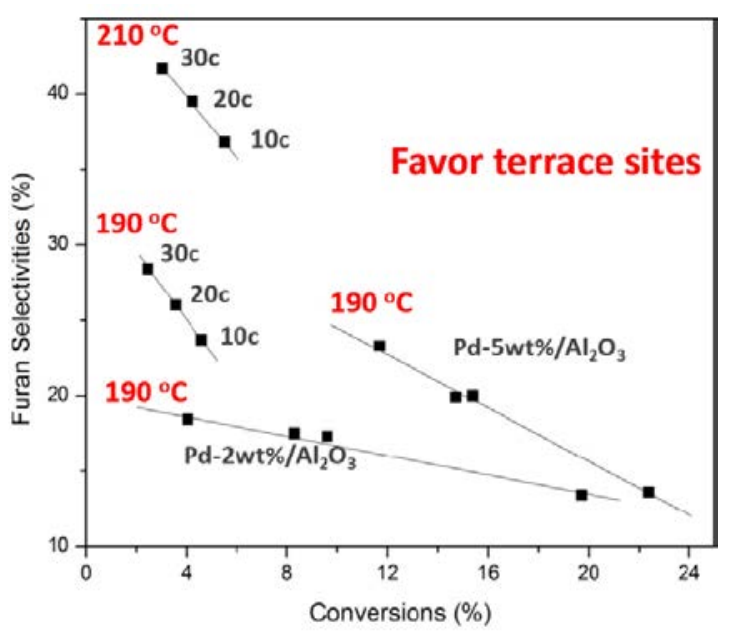

Fig. 10. Gas-phase hydrogenation of furfural. Furan selectivity (ロ) for each catalyst is plotted versus furfural hydrogenation conversion. Reprinted with permission from Ref. [28]. Copyright 2014 Wiley-VCH.

sites; thus, $\mathrm{ALD}-\mathrm{Pd} / \mathrm{Al}_{2} \mathrm{O}_{3}-10 \mathrm{c}$ should have a higher ratio of terrace to step sites than uncoated $\mathrm{Pd}-5 \mathrm{wt} \% / \mathrm{Al}_{2} \mathrm{O}_{3}$. This assumption was confirmed by $\mathrm{CO}$ chemisorption studies, where most of the defect sites of the Pd NPs were selectively covered by alumina overcoatings (Figure S2 of Ref. [28]). Thus, two methods were applied to increase the ratio between terrace and step sites of Pd NPs. These results reinforce that the furfural hydrogenation reaction is a structure-sensitive reaction with selectivity to furan increased by increasing the ratio of terrace to edge sites. By comparing to the results in the literature, this ALD modified Pd catalyst also shows some potential in commercialization in terms of activity (TOF), selectivity, and stability. The selectivity modification effect by ALD could also be attributed to tuning the concentration of either the reactants or some of the reaction intermediates on the surface of the catalyst via building up a confined environment [46,47], which is a little bit hard to quantitatively analyze. Kinetic studies with the combination of in-situ characterizations (such as FTIR etc.) might be one way to discuss this effect through estimation of the most abundant surface intermediates (MASI).

\section{Building up new catalytic systems by ALD}

\subsection{Building up new catalytic system with precise pore structure}

Beyond modification of the catalytic system, people have utilized ALD to generate new reaction systems. For example, Notestein and coworkers [40] presented an approach that adds reactant selectivity to existing, non-porous oxide catalysts by first grafting the catalyst particles with single-molecule sacrificial templates, then partially overcoating the catalyst with a second oxide through ALD. A so called sieving layer of $\mathrm{Al}_{2} \mathrm{O}_{3}$ (thickness of $0.4-0.7 \mathrm{~nm}$ ) with nanocavities less than $2 \mathrm{~nm}$ in diameter was created on a $\mathrm{TiO}_{2}$ photocatalyst, in which the selectivity towards less hindered reactants has been improved (up to 9:1). 
Up to ten cycles of $\mathrm{Al}_{2} \mathrm{O}_{3}$ were deposited to the surface of templated Degussa Evonik $\mathrm{TiO}_{2} \mathrm{P}_{25}$, a benchmark photocatalyst, where P-tert-butyl-calix[4]arene (CAL) and adamantane carboxylic acid (ACA) templates were grafted to the surface of $\mathrm{TiO}_{2}$ prior to ALD overcoating. The templates were then removed by $\mathrm{O}_{3}$ treatment at $110^{\circ} \mathrm{C}$ to reveal the underlying catalyst surface. The dimension of this cavitity generated by organic templates (CAL and ACA) selectively allows access only to molecules being able to penetrate the nanocavities. Control materials were synthesized following the same procedure without any template. The competitive photooxidation of benzyl alcohol (BzOH), 2,4,6-trimethylbenzyl alcohol (TMBzOH), 2-adamantanol (AdOH) and 1-adamantane methanol (Ad$\mathrm{MeOH}$ ) was tested over $\mathrm{TiO}_{2}$ with nanocavities on its surface (templated ALD treated sample) and the control material. Representative data are found in Figure 11b, while selective photocatalytic reduction of nitrobenzene (NB) and nitroxylene (NX) with ethanol as a sacrificial reductant was also examined (Figure 11c). Both catalysts exhibited high initial reaction rates on bare $\mathrm{TiO}_{2}$. These initial rates and conversions decreased monotonically with increasing number of cycles, consistent with increased covering on the bare $\mathrm{TiO}_{2}$ catalyst surface. The ALD coated samples showed smaller reaction rates in both cases, indicating that the active sites on the surface of $\mathrm{TiO}_{2}$ were covered by aluminate ALD. As shown in Figure 11c, the photoreduction rate could be completely shut down by ALD without templates. More interestingly, the photooxidation/reduction behaves differently on the reactant with different molecular dimensions. For example, in Figure 11d, the ratio of the initial oxidation rates for $\mathrm{BzOH}$ versus $\mathrm{TMBzOH}$ increases as ALD cycles increased over CAL-templated catalysts. There is no selectivity observed for $\mathrm{AdOH}$ versus $\mathrm{AdMeOH}$ at any number of cycles, consistent with their identical molecular cross-sections. Clearly this is typical shape-selective catalytic reaction. With ALD overcoating, people can create such kind of catalytic reaction systems.

\subsection{Building up new catalytic systems with precise active component}
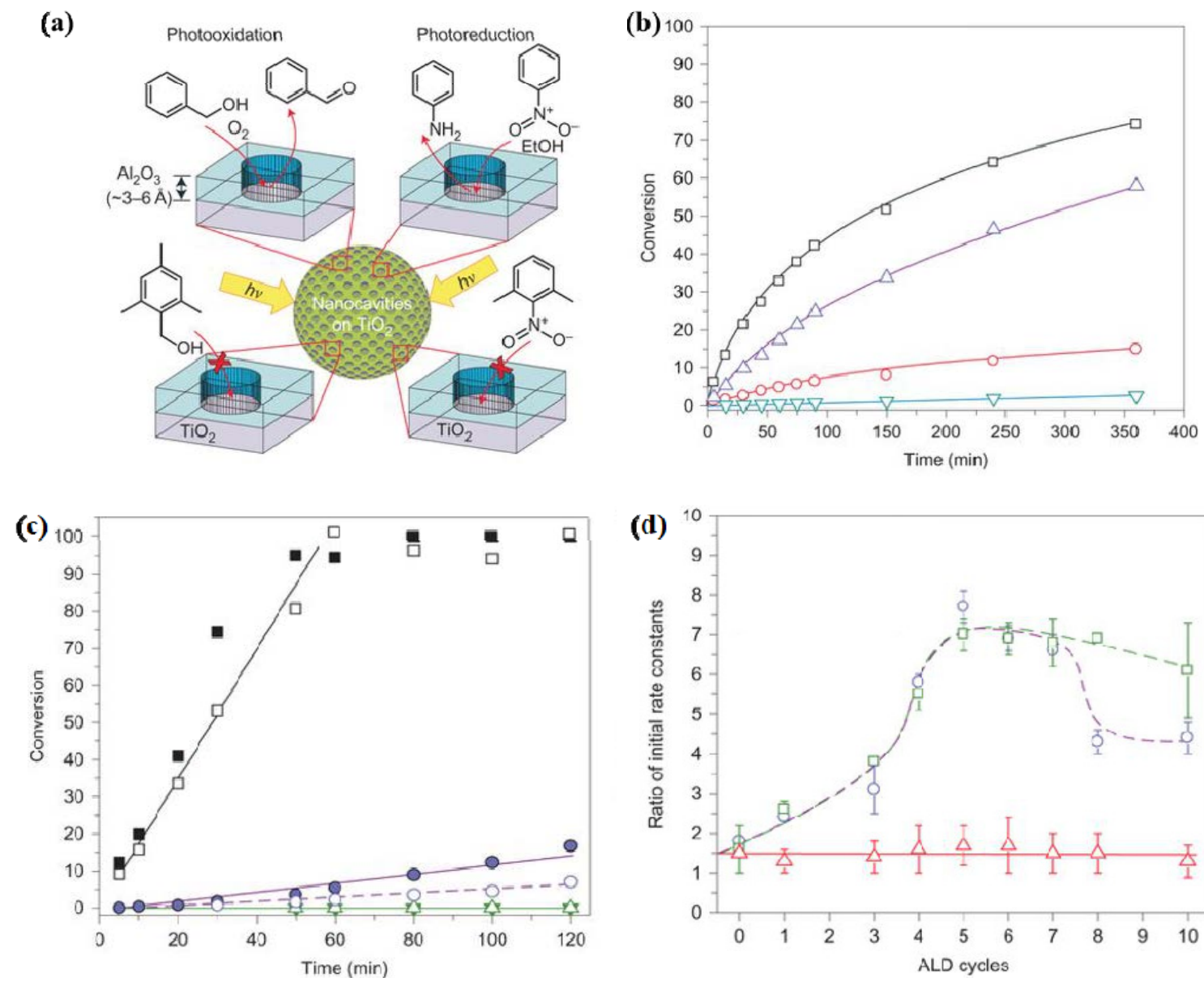

Fig. 11. (a) Selective photocatalytic oxidations and reductions of mixtures are carried out over CAL-templated nanocavities. (b) Conversions of BzOH versus $\mathrm{TMBzOH}$ are shown over bare $\mathrm{TiO}_{2}$ ( $\square: \mathrm{BzOH}$ and $\triangle: \mathrm{TMBzOH}$ ) and 5 cycles of $\mathrm{Al}_{2} \mathrm{O}_{3} \mathrm{ALD}$ on $\mathrm{CAL}-\mathrm{TiO} \mathrm{O}_{2}$ (O: Nanocavities, $\mathrm{BzOH}$ and $\nabla: \mathrm{Nanocav}-$ ities, $\mathrm{TMBzOH}$ ). (c) Conversions of nitrobenzene (NB) and nitroxylene (NX) with ethanol as a sacrificial reductant are shown over bare $\mathrm{TiO}_{2}(\mathbf{m}$ : $\mathrm{NB}$ and $\square: \mathrm{NX}$ ), 4 cycles of $\mathrm{Al}_{2} \mathrm{O}_{3}$ on $\mathrm{CAL}^{-\mathrm{TiO}} \mathrm{O}_{2}\left(\bullet: \mathrm{NB}\right.$ and $\circ$ : NX) and 5 cycles of $\mathrm{Al}_{2} \mathrm{O}_{3}$ on $\mathrm{TiO}_{2}$ without a template ( $\boldsymbol{\nabla}: \mathrm{NB}$ and $\left.\Delta: \mathrm{NX}\right)$. (d) Ratios of initial rate constants in competitive oxidations of $\mathrm{BzOH}$ versus $\mathrm{TMBzOH}(\mathrm{O})$ or $\mathrm{BzOH}$ versus $\mathrm{AdOH}(\square)$ are maximized at 4-7 cycles of $\mathrm{ALD} \mathrm{Al}_{2} \mathrm{O}_{3}$, consistent with size exclusion of larger or more hindered species once the space around the CAL template is completely filled in by the ALD process. No selectivity is observed for AdOH versus AdMeOH $(\Delta)$ at any number of cycles, consistent with their identical molecular cross-sections. In (b-d), lines are given as guides to the eye. Panels (b) and (c) are individual experimental runs. Reprinted with permission from Ref. [40]. Copyright 2012 Nature. 
With the ALD method, Lu and coworkers [48] showed that $\mathrm{Pt}_{2}$ dimers can be fabricated with a bottom-up approach on graphene using ALD, through proper nucleation sites creation. Using aberration-corrected HAADF-STEM, they showed that both the isolated $\mathrm{Pt}$ and $\mathrm{Pt}_{2}$ dimers were successfully assembled (Figure 12a-f). The mechanism is that they put mono-dispersed $\mathrm{Pt}_{1}$ single-atom to the surface of graphene (Figure 12a-c), and then attached a secondary Pt atom selectively onto the preliminary one (Figure 12d-f). Scanning transmission electron microscopy, X-ray absorption spectroscopy, and theoretical calculations suggest that the $\mathrm{Pt}_{2}$ dimers are likely in the oxidized form of $\mathrm{Pt}_{2} \mathrm{O}_{\mathrm{x}}$. In hydrolytic dehydrogenation of ammonia borane, $\mathrm{Pt}_{2}$ dimers show a high specific rate of $2800 \mathrm{~mol} \mathrm{H}_{2}$ per mol of Pt per min at room temperature, which is $\sim 17$ - and 45 -fold higher than graphene supported Pt single atoms and nanoparticles, respectively. This work sets a good example that ALD can selectively generate new catalytic systems, such as metal atom dimers, by the guidance of catalytic requirement. In addition, ALD is a very good method to generate mono-dispersed single site catalyst. For example, three separated groups (Botton [49], Sun [50] and Lu [51,52]) reported that atomically dispersed transition metal could be achieved over nitrogen doped graphene layers. Very recently, Lu et al. [53,54] reported that single site catalyst could also be assembled over g- $\mathrm{C}_{3} \mathrm{~N}_{4}$ and $\mathrm{CeO}_{2}$ supports. Collectively, ALD is a very good method to build up new catalytic systems with precise active component.

\subsection{Precisely building up complex catalytic systems}

Ideal heterogeneous tandem catalysts require rational design and integration of collaborative active sites. ALD offers an opportunity to build up multi-functional components together. For example, Qin et al. [55] reported the synthesis of a new tandem catalyst with multiple metal-oxide interfaces based on a tube-in-tube nanostructure. They used template-assisted ALD with $\mathrm{Ni}$ nanoparticles supported on the outer surface of the inner $\mathrm{Al}_{2} \mathrm{O}_{3}$ nanotube $\left(\mathrm{Ni} / \mathrm{Al}_{2} \mathrm{O}_{3}\right)$ and Pt nanoparticles attached to the inner surface of the outer $\mathrm{TiO}_{2}$ nanotube $\left(\mathrm{Pt} / \mathrm{TiO}_{2}\right)$. High-angle annular dark field scanning transmission electron microcopy (HAADF-STEM) and energy-dispersive X-Ray spectrometry (EDX) analysis (Figure 13a, b) were used to reveal the local elemental distribution of $\mathrm{Al} / \mathrm{Ni}-\mathrm{Pt} / \mathrm{Ti}$ catalyst. The tandem catalyst shows remarkably high catalytic efficiency in nitrobenzene hydrogenation over $\mathrm{Pt} / \mathrm{TiO}_{2}$ with hydrogen formed in-situ by the decomposition of hydrazine hydrate over $\mathrm{Ni} / \mathrm{Al}_{2} \mathrm{O}_{3}$. As shown in Figure 13c, the catalytic activity of the $\mathrm{Al} / \mathrm{Ni}-\mathrm{Pt} / \mathrm{Ti}$ catalyst is significantly higher than that of the $\mathrm{Al} / \mathrm{Ni}-\mathrm{Ti}$ and $\mathrm{Al}-\mathrm{Pt} / \mathrm{Ti}$ catalysts with a single metal-oxide interface. Almost no reaction occurs over the Al-Pt/Ti catalyst, and little aniline is observed over $\mathrm{Al} / \mathrm{Ni}$ - Ti catalyst. This can be ascribed to the synergistic effect of the two interfaces and the confined nanospace favoring the penetration of intermediates. The tube-in-tube tandem catalyst with multiple metal-oxide interfaces represents a new concept for the design of highly efficient and multifunctional nanocatalysts. In addition, Qin et al. [29] also shows that ALD could easily assemble nickle inside or outside of carbon nanotube channels or generate multi-metal support interfaces following designed sequential process [56]. ALD has great flexibility on constructing nanostructured metal catalysts at the atomic level.

\section{Conclusions}

In this review paper, we summarize the effect of ALD for both catalytic modification and generating new catalytic systems. ALD overcoating can change the redox properties of the nanoparticle covered. In most cases, both the reduction and oxidation of the nanoparticle underneath were delayed by ALD. In addition, ALD overcoating initiates from the step sites, then moves to the terrace sites in which case the reaction selectivity was modified, especially on furfural hydrogenation reaction
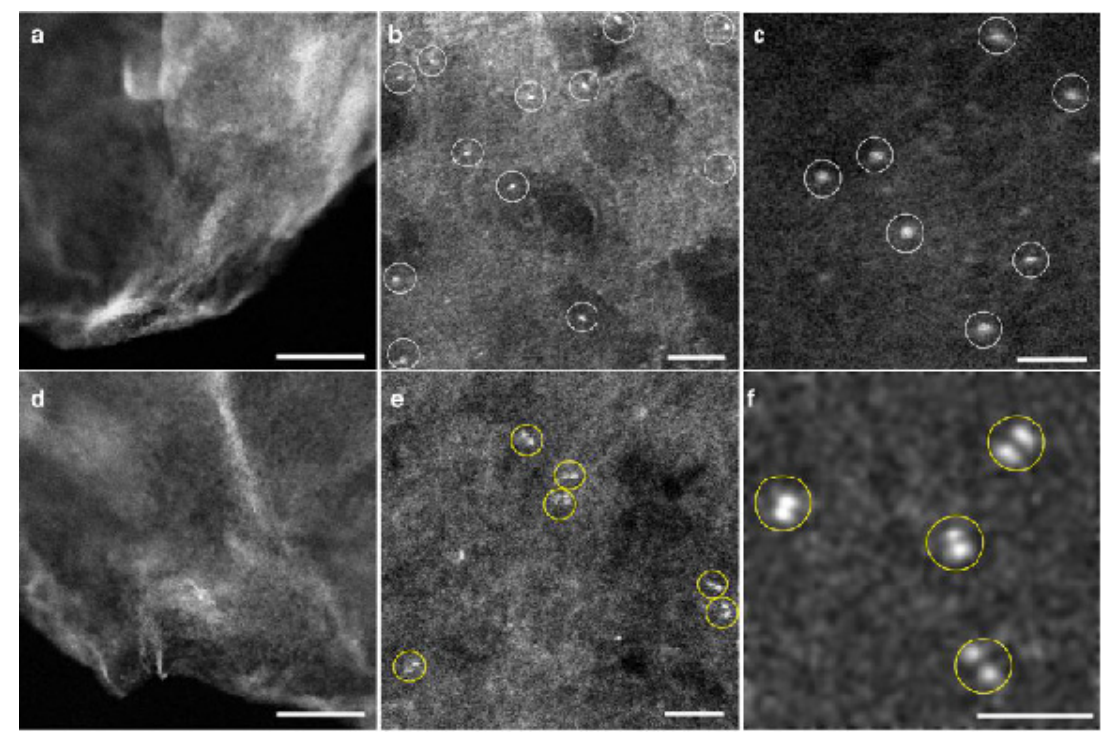

Fig. 12. Morphology of the single-atom $\mathrm{Pt}_{1}$ /graphene and dimeric $\mathrm{Pt}_{2}$ /graphene catalysts. Aberration-corrected HAADF-STEM images of $\mathrm{Pt}_{1}$ /graphene (a-c) and dimeric Pt 2 /graphene (d, e). Scale bars, $20 \mathrm{~nm}(\mathrm{a}, \mathrm{d}), 2 \mathrm{~nm}(\mathrm{~b}, \mathrm{e})$, and $1 \mathrm{~nm}(\mathrm{c}, \mathrm{f})$. Pt single atoms in (b) and (c) and dimers in (e and (f) are highlighted by white and yellow circles, respectively. Reprinted with permission from Ref. [48]. Copyright 2005 Elsevier. 

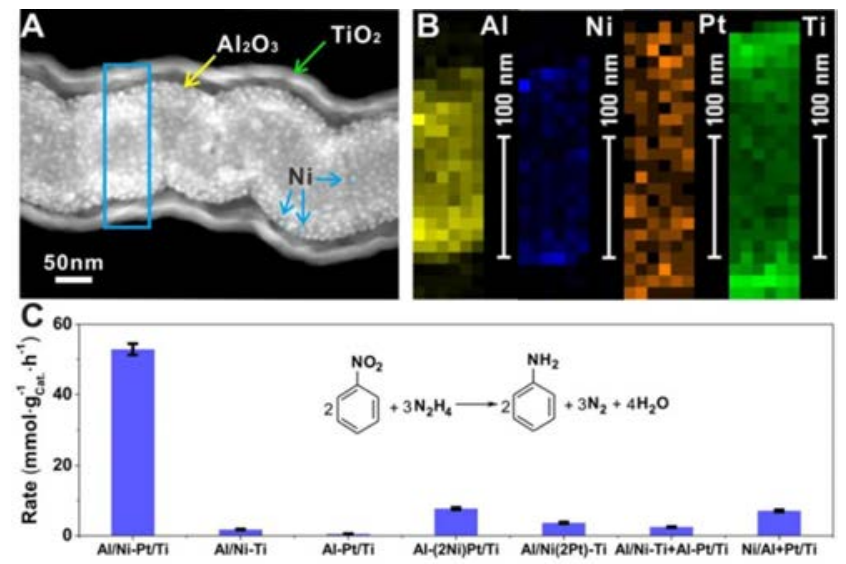

Fig. 13. (A) HAADF-STEM image of $\mathrm{Al} / \mathrm{Ni}-\mathrm{Pt} / \mathrm{Ti}$. (B) EDX elemental mapping for the boxed area in (A). (C) Catalytic activity of different catalysts for nitrobenzene hydrogenation using $\mathrm{N}_{2} \mathrm{H}_{4} \cdot \mathrm{H}_{2} \mathrm{O}$ as a hydrogen source. Adapted with permission from Ref. [55]. Copyright 2016 Wiley-VCH.

and ethane oxi-dehydrogenation reaction. The ALD on the surface of the nanoparticles, or the metal oxide substrates are amorphous most of the time. Some nano-pores were generated by calcination, which could be clearly monitored by SAXS. With ALD overcoating, the coke formation, leaching of the catalyst, sintering of the active components would be prohibited. Thus reaction stability was improved. Beyond modification, new catalytic systems with uniform distribution of pore size in the ALD layer or precise structural of active component could be fabricated with ALD. ALD is a promising technique for catalyst preparation and modification. It starts a new generation for catalysis.

\section{Acknowledgments}

We thank Ms Jingjing Dai for helpful discussions. This material is based upon work supported as part of the Institute for Atom-efficient Chemical Transformations (IACT), an Energy Frontier Research Center funded by the U.S. Department of Energy, Office of Science, Office of Basic Energy Sciences. Use of the Advanced Photon Source is supported by the U.S. Department of Energy, Office of Science, and Office of the Basic Energy Sciences, under Contract DE-AC-02-06CH11357.

\section{References}

[1] C. Adams, Top. Catal., 2009, 52, 924-934.

[2] V. Aleskovsky, M. Koltcov, USSR Patent 422446, 1972.

[3] T. Suntola, J. Antson, U.S. Patent 4058430 A, 1977.

[4] J. Lu, J. W. Elam, P. C. Stair, Acc. Chem. Res., 2013, 46, 1806-1815.

[5] Z. Gao, Y. Qin, Acc. Chem. Res., 2017, 50, 2309-2316.

[6] B. J. O'Neill, D. H. K. Jackson, J. Lee, C. Canlas, P. C. Stair, C. L. Marshall, J. W. Elam, T. F. Kuech, J. A. Dumesic, G. W. Huber, ACS Catal., 2015, 5, 1804-1825.

\section{Graphical Abstract}

Chin. J. Catal., 2019, 40: 1311-1323 doi: S1872-2067(19)63321-8

Atomic layer deposition: Catalytic preparation and modification technique for the next generation

Hongbo Zhang *, Christopher L. Marshall *

Nankai University, China; Argonne National Laboratory, USA

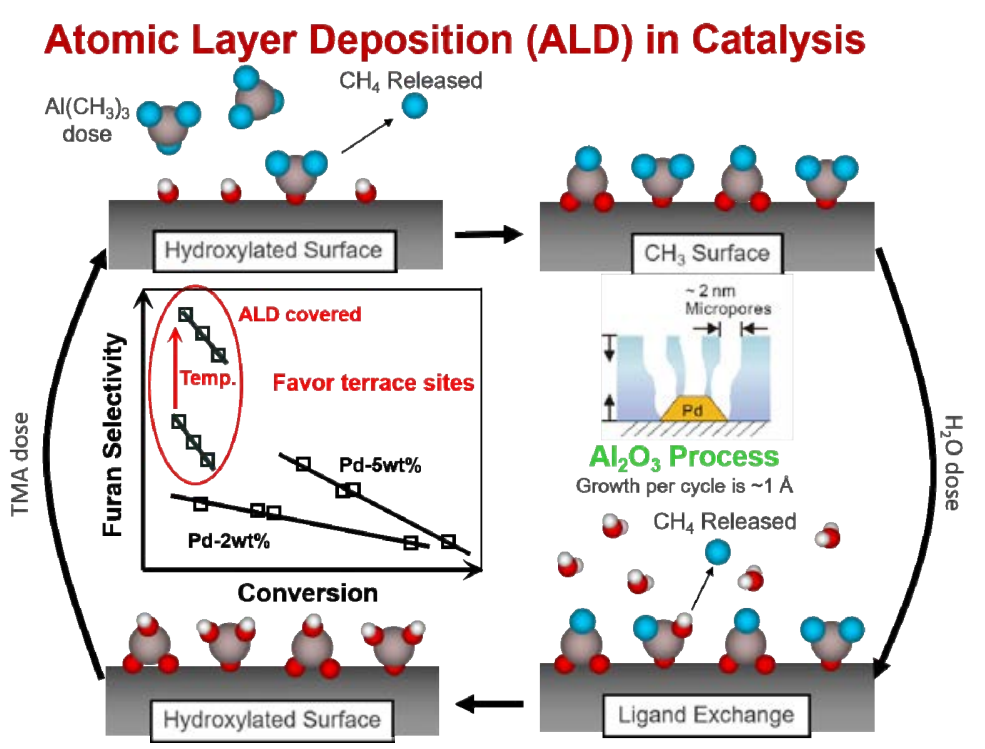

This mini-review describes the advantages of atomic layer deposition in catalyst preparation and modification. Specifically, people could use this technique to improve the catalytic stability, tune the reaction selectivity and enhance the reaction activity. 
[7] J. Lu, B. Fu, M. C. Kung, G. Xiao, J. W. Elam, H. H. Kung, P. C. Stair, Science, 2012, 335, 1205-1208.

[8] H. W. Wang, J. L. Lu, Acta Phys.-Chim. Sin., 2018, 34, 1334-1357.

[9] J. L. Lu, J. W. Elam, P. C. Stair, Surf. Sci. Rep., 2016, 71, 410-472.

[10] M. S. Chen, D. W. Goodman, Science, 2004, 306, 252-255.

[11] X. Xie, Y. Li, Z. Liu, M. Haruta,W. Shen, Nature, 2009, 458, 746-749.

[12] J. M. Thomas, Nature, 1994, 368, 289-290.

[13] J. M. Thomas, G. N. Greaves, Science, 1994, 265, 1675-1676.

[14] Q. Fu, W. X. Li, Y. Yao, H. Liu, H. Y. Su, D. Ma, X. K. Gu, L. Chen, Z. Wang, H. Zhang, B. Wang, X. Bao, Science, 2010, 328, 1141-1144.

[15] X. Guo, G. Fang, G. Li, H. Ma, H. Fan, L. Yu, C. Ma, X. Wu, D. Deng, M. Wei, D. Tan, R. Si, S. Zhang, J. Li, L. Sun, Z. Tang, X. Pan, X. Bao, Science, 2014, 344, 616-619.

[16] Q. Fu, X. Bao, Chem. Soc. Rev., 2017, 46, 1842-1874.

[17] W. Chen, Z. Fan, X. Pan, X. Bao, J. Am. Chem. Soc., 2008, 130, 9414-9419.

[18] D. Teschner, J. Borsodi, A. Wootsch, Z. Révay, M. Hävecker, A. Knop-Gericke, S. D. Jackson, R. Schlögl, Science, 2008, 320, 86-89.

[19] A. D. Johnson, S. P. Daley, A. L. Utz, S. T. Ceyer, Science, 1992, 257, 223-225.

[20] V. Ledentu, W. Dong, P. Sautet, J. Am. Chem. Soc., 2000, 122, 1796-1801.

[21] S. M. George, Chem. Rev., 2010, 110, 111-131.

[22] J. S. Lim, ICVC'99 6th International Conference, 1999, 506-509.

[23] K. Mistry, C. Ailen, C. Auth, et al., in: 2007 IEEE International Electron devices Meeting, Washington, 2007, 247-250.

[24] C. Bernay, A. Ringuedé, P. Colomban, D. Lincot, M. Cassir, J. Phys. Chem. Solids, 2003, 64, 1761-1770.

[25] J. R. Bakke, K. L. Pickrahn, T. P. Brennan, S. F. Bent, Nanoscale, 2011, 3, 3482-3508.

[26] B. J. O'Neill, D. H. K. Jackson, A. J. Crisci, C. A. Farberow, F. Shi, A. C. Alba-Rubio, J. Lu, P. J. Dietrich, X. Gu, C. L. Marshall, P. C. Stair, J. W. Elam, J. T. Miller, F. H. Ribeiro, P. M. Voyles, J. Greeley, M. Mavrikakis, S. L. Scott, T. F. Kuech, J. A. Dumesic, Angew. Chem. Int. Ed., 2013, 52, 13808-13812.

[27] H. Zhang, Y. Lei, A. J. Kropf, G. Zhang, J. W. Elam, J. T. Miller, F. Sollberger, F. Ribeiro, M. C. Akatay, E. A. Stach, J. A. Dumesic, C. L. Marshall, J. Catal., 2014, 317, 284-292.

[28] H. Zhang, X. K. Gu, C. Canlas, A. J. Kropf, P. Aich, J. P. Greeley, J. W. Elam, R. J. Meyers, J. A. Dumesic, P. C. Stair, C. L. Marshall, Angew. Chem. Int. Ed., 2014, 53, 12132-12136.

[29] Z. Gao, M. Dong, G. Wang, P. Sheng, Z. Wu, H. Yang, B. Zhang, G. Wang, J. Wang, Y. Qin, Angew. Chem. Int. Ed., 2015, 54, 9006-9010.

[30] C. Wang, H. Wang, Q. Yao, H. Yan, J. Li, J. Lu, J. Phys. Chem. C, 2016, $120,478-486$.

[31] Q. Yao, C. Wang, H. Wang, H. Yan, J. Lu, J. Phys. Chem. C, 2016, 120, 9174-9183.

[32] F. H. Fabreguette, Z. A. Sechrist, J. W. Elam, S. M. George, Thin Solid Films, 2005, 488, 103-110.
[33] A. Alejandre, F. Medina, P. Salagre, X. Correig, J. E. Sueiras, Chem. Mater., 1999, 11, 939-948.

[34] M. K. Neylon, C. L. Marshall, A. J. Kropf, J. Am. Chem. Soc., 2002, $124,5457-5465$

[35] N. B. Castagnola, A. J. Kropf, C. L. Marshall, Appl. Catal. A, 2005, 290, 110-122.

[36] H. Zhang, Y. Lei, A. J. Kropf, G. Zhang, J. W. Elam, J. T. Miller, F. Sollberger, F. Ribeiro, M. C. Akatay, E. A. Stach, J. A. Dumesic, C. L. Marshall, J. Catal., 2015, 317, 284-292.

[37] H. Feng, J. Lu, P. C. Stair, J. W. Elam, Catal. Lett., 2011, 141, 512-517.

[38] S. Schauermann, J. Hoffmann, V. Johanek, J. Hartmann, J. Libuda, H. J. Freund, Angew. Chem. Int. Ed., 2002, 41, 2532-2535.

[39] T. Li, A. J. Senesi, B. Lee, Chem. Rev., 2016, 116, 11128-11180.

[40] C. P. Canlas, J. Lu, N. A. Ray, N. A. Grosso-Giordano, S. Lee, J. W. Elam, R. E. Winans, R. P. Van Duyne, P. C. Stair, J. M. Notestein, Nat. Chem., 2012, 4, 1030-1036.

[41] F. Cavani, N. Ballarini, A. Cericola, Catal. Today, 2007, 127, 113-131.

[42] P. Concepción, M. T. Navarro, T. Blasco, J. M. López Nieto, B. Panzacchi1, F. Rey, Catal. Today, 2004, 96, 179-186.

[43] Z. S. Chao, E. Ruckenstein, J. Catal., 2004, 222, 17-31.

[44] K. D. Chen, A. T. Bell, E. Iglesia, J. Phys. Chem. B, 2000, 104, 1292-1299.

[45] S. H. Pang, C. A. Schoenbaum, D. K. Schwartz, J. W. Medlin, Nat. Commun., 2013, 4, 2448-2453.

[46] H. Yi, H. Y. Du, Y. L. Hu, H. Yan, H.-L. Jiang, J. L. Lu, ACS Catal., 2015, 5, 2735-2739.

[47] H. Yi, Y. J. Xia, H. Yan, J. L. Lu, Chin. J. Catal., 2017, 38, 1581-1587.

[48] H. Yan, Y. Lin, H. Wu, W. Zhang, Z. Sun, H. Cheng, W. Liu, C. Wang, J. Li, X. Huang, T. Yao, J. Yang, S. Wei, J. Lu, Nat. Commun., 2017, 8, 1-11.

[49] S. Stambula, N. Gauquelin, M. Bugnet, S. Gorantla, S. Turner, S. Sun, J. Liu, G. Zhang, X. Sun, G. A. Botton, J. Phys. Chem. C, 2014, 118, 3890-3900.

[50] N. C. Cheng, S. Stambula, D. Wang, M. N. Banis, J. Liu, A. Riese, B. W. Xiao, R. Y. Li, T. K. Sham, L. M. Liu, G. A. Botton, X. L. Sun, Nat. Commun., 2016, 7, 13638/1-13638/9.

[51] H. Yan, H. Cheng, H. Yi, Y. Lin, T. Yao, C. Wang, J. Li, S. Wei, J. Lu, J. Am. Chem. Soc., 2015, 137, 10484-10487.

[52] Y. Cao, S. Chen, Q. Luo, H. Yan, Y. Lin, W. Liu, L. Cao, J. Lu, J. Yang, T. Yao, Angew. Chem. Int. Ed., 2017, 56, 12191-12196.

[53] X. Huang, Y. Xia, Y. Cao, X. Zheng, H. Pan, J. Zhu, C. Ma, H. Wang, J. Li, R. You, S. Wei, W. Huang, J. Lu, Nano Res., 2017, 10, 1302-1312.

[54] C. Wang, X. K. Gu, H. Yan, Y. Lin, J. Li, D. Liu, W. X. Li, J. Lu, ACS Catal., 2017, 7, 887-891.

[55] H. Ge, B, Zhang, X. Gu, H. Liang, H. Yang, Z. Gao, J. Wang, Y. Qin, Angew. Chem. Int. Ed., 2016, 55, 7081-7085.

[56] X. Liu, Q. Q. Zhu, Y. Lang, K. Cao, S. Q. Chu, B. Shan, R. Chen, Angew. Chem. Int. Ed., 2017, 56, 1648-1652.

\title{
原子层沉积技术: 催化剂合成与修饰新工艺
}

\author{
张洪波, ${ }^{\mathrm{a},}$, Christopher L. Marshall ${ }^{\mathrm{b}, \#}$ \\ a 南开大学材料科学与工程学院, 国家新材料研究院, 天津 300350, 中国 \\ b 阿贡国家实验室化学科学与工程分部, 莱蒙特, 伊利诺伊州, 美国
}

摘要: 近年来, 原子层沉积(ALD)技术以其精准的材料合成及修饰特性(精确到原子尺度)吸引了广泛关注. 特别地, ALD技 术在新型纳米催化材料研发方面表现优异. 这集中体现在对催化反应稳定性的提高和对催化反应选择性的调变, 如本文 
中列举的 $\mathrm{Pd} / \mathrm{Al}_{2} \mathrm{O}_{3}$ 和Cu-chromite体系等都很好地展示了 ALD技术对不同催化反应体系的调控作用. 目前, 已有一系列相关 的综述性文章发表, 从不同侧面讨论了ALD技术对催化反应的影响. 但是, 有关ALD技术的作用机理尚未见明确表述, 尤 其关于ALD纳米层如何在原子和分子水平上调变催化剂纳米粒子, 从而影响催化反应稳定性与选择性等方面的讨论尚不 充分.

本综述简要介绍了ALD技术的由来和发展历程; 归纳了前人采用X射线吸收光谱(XAFS), 程序升温还原/氧化 (TPR/TPO)、CO化学吸附(FTIR)和X射线小角衍射(SAXS)等方法研究ALD技术对被覆盖的催化剂纳米颗粒氧化还原特性 及表面活性位组成影响的实验结果, 包括借助ALD手段调控催化剂的孔分布; 列举了应用该手段提高催化反应稳定性、调 变催化反应选择性的实例; 讨论了ALD特有的“自终止”(“self-limiting”)特性; 总结了ALD纳米层通过电子效应和结构效应 等形式对催化反应产生的影响. 本文还介绍了部分有关借助ALD技术构建新型纳米反应体系的研究进展, 包括构建新型 纳米限域体系(“nano-bowl”)并将该限域体系应用于选择性(催化转化特定尺寸的反应底物)光催化转化反应过程, 以及构建 双中心纳米催化体系(Pt-dimer, 在预先吸附的单中心Pt催化剂周围再次吸附单分散的Pt), 同时还讨论了如何利用ALD技术 构建多元、多界面催化反应体系.

关键词: 原子层沉积; 催化剂修饰; 催化剂制备; 氧化还原特性; 平整表面; 台阶位

收稿日期: 2019-01-05. 接受日期: 2019-01-30. 出版日期: 2019-09-05.

*通讯联系人. 电话: 18522166403; 电子信箱: hbzhang@nankai.edu.cn

\#通讯联系人. 电子信箱: Marshall@anl.gov

基金来源：美国能源部 (DE-AC-02-06CH11357).

本文的电子版全文由Elsevier出版社在ScienceDirect上出版(http://www.sciencedirect.com/science/journal/18722067). 